\title{
DIAGNOSA KETERAMPILAN MENGAJAR GURU PAI PADA MATERI YANG DIANGGAP TABU DI SDIT AL-FIRDAUS BANJARMASIN
}

\author{
Nuryadin $^{1}$, Abdullah Husein ${ }^{2}$ \\ ${ }^{1}$ Program Studi PAI, Universitas Islam Negeri Antasari, ${ }^{2}$ STIT Darul Hijrah \\ ${ }^{1}$ yadin.dpkfakhukum@gmail.com, ${ }^{2}$ husninabdullah93@gmail.com
}

\begin{abstract}
Abstrak: Materi Fiqih memerlukan sebuah keterampilan khusus bagi seorang pendidik dalam menyampaikannya, apalagi bersinggungan masalah penyampaian materi yang dianggap tabu baik oleh pendidik maupun peserta didik. Seperti penyampaian materi tentang bersuci dari hadas besar (Mandi Junub), juga penyampaian materi membatalkan shalat, dan puasa (Haid, Nifas Jimak). Keterampilan seorang guru sangatlah diperlukan guna bisa menyampaikan materi yang tabu dalam Fiqih kepada peserta didik jenjang sekolah dasar dengan sesuai proporsinya. Artikel ini bertujuan untuk menganalisis keterampilan seorang pendidik dalam menyampaikan materi Fiqih yang tabu guna memberikan pemahaman kepada peserta didik jenjang sekolah dasar. Artikel ini akan dikaji menggunakan metode penelitian kualitatif deskriptif dengan terjun langsung ke lapangan mencari data dan dinarasikan data tesebut sejalan dengan teori yang bersangkutan. Hasil penelitian ini pendidik perlu keterampilan khusus dalam mengajar agar bisa menyampaikan materi Fiqih yang dianggap tabu kepada peserta didik jenjang sekolah dasar dengan baik dan sesuai proporsi. Simpulan dari penelitian ini keterampilan menyampaikan materi Fiqih dari pendidik dapat memberikan pemahaman kepada peserta didik pada materi Fiqih yang dianggap tabu.
\end{abstract}

\section{Kata Kunci: Materi Fiqih, Pendidik, Tabu}

\section{DIAGNOSING THE SKILL OF TEACHING OFPAI TEACHERS ON THE SUBJECTS THAT ARE TABOO AT SDIT AL FIRDAUS BANJARMASIN}

\begin{abstract}
Fiqh material requires a special skill for an educator in delivering it, let alone intersect with the problem of delivering material that considered taboo by both educators and students. Like delivering material about the purification of the big hadas (Mandi Junub), also conveyed the material of the request prayer, and fasting (Haid, Nifas Jimak). The skills of a teacher are needed in order to convey taboo material in Fiqh to level students elementary school in proportion. This article aims to analyze the skills of an educator in delivering Fiqh material which is taboo provide understanding to elementary school students. This article will studied using descriptive qualitative research methods by going directly to the field searches for data and narrates the data with a theory that concerned. The results of this study educators need special skills in teaching in order to be able to convey Fiqh material that is considered taboo to level students elementary school properly and in proportion. Conclusions from this research skills delivering Fiqh material from educators can provide understanding to participants educate on Fiqh material which is considered taboo.
\end{abstract}

Keyword: Fiqh material, educator, taboo 


\section{PENDAHULUAN}

Pendidikan yang menjadi lembaga tolak ukur kemajuan suatu bangsa sebagai wadah pengembangan sumber daya manusia (SDM) (Hadi, 2021) Pendidikan Islam terutama di era digital ini berguna untuk membentuk generasi muslim yang cakap dan memiliki ilmu pengetahun juga keterampilan yang mempuni agar dapat beradaptasi dengan zaman. Pendidikan Islam harus bisa dirancang untuk membuat seorang muslim tidak hanya cakap pada keilmuan tetapi bisa memberikan praktis keilmuan pada masyarakat luas atau umat secara menyeluruh. Aspek keimanan dan keahlian harus bisa berinergi guna dapat mewujudkan seorang muslim dengan tanggung jawab sebagai hamba yang tidak melupakan posisinya sebagai seorang manusia yang hidup di dunia dengan berbagai perubahan zaman (Alfinnas, 2018).

Pembentukan akhlak mulia pada setiap individu guna menjadiakan manusia sebagai khalifah di muka bumi merupakan tujuan dari pendidikan Islam ini, selain itu peran lain dari pendidikan Islam juga bertugas memberikan sebuah jalan untuk seorang individu bisa mengembangkan segala potensi yang pada diri seorang individu bisa terbentuk secara maksimal (Wijaya, Wibowo, Supriadi, \& Sopyan, 2020).

Manusia sebagai khalifah dimuka bumi akan selalu melakukan hubunganhubungan kerja sama guna memenuhi atau menyelesaikan suatu masalah. Islam memberikan dua jalur hubungan kepada manusia secara umum yaitu hubungan secara vertikal yaitu kepada Allah dalam bentuk akidah atau ibadah dan hubungan horizontal yaitu hubungan antar manusia bisa disebut sebagai muamalah. Kajian muamalah atau bisa kita sebut sebagai pembelajaran fiqih (Syaifullah, 2020).

Pembelajaran fiqih atau kajian tentang ilmu fiqih sangatlah luas dan berbagai pendapat dapat kita temukan, pembelajaran fiqih ini tidak hanya dipelajari diperguruan tinggi tetapi sudah dikenalkan dasarnya seminimal mungkin atau sedasar mungkin pada jenjang sekolah dasar. Di sekolah dasar pembelajaran fiqih sangatlah urgen dan sudah menyetuh ranah bersuci juga ibadah wajib lainnya, di mana dalam pembahasan ini bersuci adalah hal pokok dan utama dalam menentukan sah atau tidaknya ibadah wajib kita secara hukum fiqih(Tang, 2018). Jenjang pendidikan sekolah dasar pembelajaran fiqih tidak diajarkan secara terpisah atau memiliki mata pelajaran sendiri, tetapi tergabung ke dalam mata pealajaran pendidikan agama Islam (PAI), dalam mata pelajaran PAI di Sekolah Dasar (SD) salah satu materinya mengajarkan cara bersuci dan ibadah wajib sholat juga puasa. Pengajaran materi ini tidak hanya sebatas pada tataran teori, tetapi memerlukan sebuah praktik guna dapat memberikan pemahaman secara menyeluruh kepada peserta didi. Pembelajaran fiqih yang sudah menyentuh tentang hal bersuci seperti mandi wajib, haid dan lain sebagainya harus bisa dijelaskan dengan keterampilan dan strategi yang tepat ditingkat dasar ini pembelajaran fiqih harus bisa variatif guna memberikan fokus dan pemahaman kepada peserta didik (Ruwaida, 2019).

Pengetahuan tentang haid, mandi wajib, hal yang membatalkan puasa seperti jimak dan keluar mani, bisa mereka ketahui sendiri tanpa melalui pemberian materi dari seorang pendidik. Hal ini diakibatkan perkembangan zaman sekarang yang masuk ke dalam zaman digitalisasi. digitalisasi memberikan banyak pilihan dalam kehidupan kita sekarang, tidak bisa kita pungkiri perubahan yang terjadi di dunia kita sekarang ini sangatlah masif. Masa ini membuat semua hal terasa sangat cepat berlalu, masa ini bisa dikatakan sebagai era disruptif, di mana semua batasan yang ada terasa hilang akibatnya kemajuan teknologi zaman sekarang. Arus internet semakin mudah untuk diakses dari segala umur, tidak terkecuali anak-anak. Saat arus digital ini sangat kuat maka muncul permasalan lain berupa mudahnya segala hal untuk diakses dan didapatkan juga tanpa 
filter yang jelas. Sehingga muncul dampak positif dan negatif dari era digitalisasi ini. Fakta dilapangan saat ini mengatakan anak-anak sudah bisa mengakses internet secara mandiri, hal ini menyebabkan anak-anak mudah terpengaruh hal negatif(Maulidiyah, 2018).

Perkembangan anak pada zaman digital ini sangat terpengaruh oleh teknologi dalamkemudahannya mengakses berbagai informasi secara daring,pada era digital sekarang ini akses informasi tanpa ada batas ruang dan waktu. Selain itu dalam era digital ini media sosial sangatlah berperan dalam penyebaran informasi.Secara istilah media sosial dapat diartikan sebagai sarana bagi individu untuk bebagi informasi teks, gambar, audio dan video dengan satu sama lain (Siagian, Martiwi, \& Indra, 2020).

Pengaruh media sosial di era digital ini sangatlah besar kepada setiap individu yang menggunakannya, tidak terkecuali anak-anak. Anak-anal pada zaman sekarang akan mudah terpengaruh oleh semua hal yang ada di media sosial. Pengaruh ini mengakibatkan berbagai hal salah satunya anak-anak bisa mengakses berbagai hal tentang materi fiqih yang berkaitan dengan hal yang membatalkan puasa seperti jimak, anak-anak bisa mengetahui hal tersebut tanpa hal ini jika tidak di intervensi atau dikontrol akan mengakibatkan anak-anak yang berangkat dari rasa penasaran untuk mengetahui hal tersebut. Materi fiqih mengenai hal tersebut dianggap sebagai materi yang tabu atau canggung, kecanggungan seorang pendidik dalam menyampaikan hal tersebut harus dibarengi dengan keterampilan mengajar(Amelia, 2020).

Materi fiqih yang berkenaan dengan hal tersebut harus bisa disampaikan dengan baik, menggunakan keterampilan dan strategi yang mempuni dari seorang pendidik. Keterampilan mengajar merupakan seperangkat kemampuan atau kecakapan dalam memfasilitasi pembelajaran peserta didik untuk mencapai tujuan pembelajaran baik secara langsung atau pun tidak langsung. Keterampilan mengajar berupa sebuah kompetensi pedagogik yang cukup kompleks karena merupakan integrasi dari berbagai kompetensi guru secara menyeluruh (Juandi \& Sontani, 2017).

Penyampaian materi fiqih tentang hal yang tabu tersebut harus di sinergikan dengan keterampilan mengajar seorang guru sejalan dengan penelitian alwiyah dan Imaniyanti terdapat pengaruh positif dan signifikan keterampilan mengajar guru terhadap hasil belajar peserta didik, terdapat kesiapan belajar peserta didik terhadap hasil belajarnya dan ada dampak positif dan signifikan antara keterampilan mengajar dan kesiapan peserta didik terhadap hasil belajarnya (Alwiyah \& Imaniyati, 2018). Berdasarkan penelitian tersebut maka dapat ditarik simpulan bahwa keterampilan pendidik sangat diperlukan guna memberikan hasil belajar yang baik kepada peserta didik. Perlu ditekankan bahwa materi yang tabu dalam fiqih perlu disampaikan dengan keterampilan mengajar yang mempuni guna memahamkan dan mencapaikan tujuan pembelajaran.

Keterampilan mengajar seorang pendidik sangat perlu untuk ditanamkan sebagai sarana mempermudah tercapainya tujuan pembelajaran, keterampilan mengajar seorang guru merupakan sebuah upaya inovatif dalam pembelajaran yang harus selalu dikembangkan guna adaptasi terhadap perkembangan zaman. Salati Asmahasanah dkk, pernah melakukan peneltian tentang analisis keterampilan mengajar guru. Hasil dari penelitian tersebut keterampilan mengajar guru harus bisa memanfaatkan lingkungan belajar dengan baik, seperti penggunaan taman atau kebun sekolah. Penggunaan taman sekolah sebagai media penunjang belajar dapat memberikan peserta didik sebuah pengalaman belajar baru, pengalaman ini akan membuat bisa merasakan lingkungan belajar alami. Dalam pemanfaatan kebun sekolah sebagai media pembelajaran alami 
dapat meningkatkan nilai positif, kecerdasan naturalistik dan rasa lebih menghargai lingkungan(Asmahasanah, Sa'diyah, \& Ibdalsyah, 2018). Dapat kita lihat dalam penelitian hendaknya keterampilan guru dalam mengajar harus selalu di kembang, juga perlu kita tekankan kemampuan dalam memanfaatkan lingkungan sekolah sebagai media pembelajaran adalah sebuah keterampilan mengajar yang bagus dari seorang pendidik.

Melihat hasil penelitian dari Maryance tentang keterampilan dasar mengajar PAI di SMPN 17 Palembang, berangkat dari penelitian yang dilakukan oleh Maryance keterampilan mengajar guru dalam materi PAI membuat pembelajaran bisa tersampai secara efektif, membuat daya tarik pembelajaran PAI bertambah oleh peserta didik, meningakatkan minat peserta didik dalam belajar PAI dan lebih bagsunya dengan keterampilan mengajar tersebut memberikan motivasi untuk peserta didik dalam belajar PAI. Penting diperhatikan tentang keterampilan belajar seorang guru, karena sebagus apapun kurikulum dan strategi yang diciptakan tidak akan bisa berkembanga tanpa diiringan keterampilan mengajar dari seorang guru(Maryance, 2017).

Melihat dari latar belakang masalah yang muncul dan diperkuat dengan penelitian yang sudah dilakukan oleh banyak orang maka perlu kiranya diadakan penelitian lebih lanjut tentang keteranpilan guru dalam menyampaikan materi khususnya pada materi fiqih yang kita anggap tabu, jika tidak dibarengi dengan keterampilan yang mempuni maka materi tabu tersebut tidak dapat tersampaikan dengan baik, apalagi perlu diingat bahwa materi tabu yang dimaksud dalam artikel ini adalah materi tentang mandi wajib, haid, hal yang membatalkan puasa seperti jimak dan keluar air mani. Semua materi terebut hari dapat terampaikan dengan baik guna memberikan pemahaman kepada peserta didik secara langsung dan sesuai dengan kapasitasnya sebagai peserta didik, jika hal ini tidak begitu diperhatikan maka peserta didik dengan rasa penasarannya akan mencari sendiri materi tersebut.

Perlunya keterampilan mengajar guru PAI apalagi tentang materi fiqih yang dianggap tabu masih tidak begitu tersentuh, berangkat dari hal terebut maka perlu kiranya kita melakukan penelitian tentang permasalahan terebut berupa bagaimana keterampilan guru PAI dalam menyampaikan materi fiqih yang dianggap tabu, kenapa penelitian harus dilakukan agar materi yang dianggap tabu tersebut dapat tersampaikan dengan baik kepada peerta didik, selain tersampaikan dengan baik juga dapat dipahami sesuai kapasitasnya sebagai peserta didik serta tidak membuat mereka mencari sendiri materi tersebut tanpa filter dan bimbingan dari orang terdidik.

\section{METODE}

Penelitian ini akan dikaji menggunakan metode penelitian kualitatif, yakini penelitian yang menberikan sebuah kedalam dalam penggalian data. Metode penelitian ini akan didukung dengan pendekatan dekriptif, dalam pendekatan ini penggalian data dan pendekripsian dilakukan dalam rangka menemukan pemahaman-pemahaman baru (Sulistiono, 2019) tentang keterampilan mengajar guru pada materi fiqih yang dianggap tabu di SDIT Al-Firdaus Banjarmasin.Jl. Sungai Gampa RT. 21 Kelurahan Sungai Jingah, Kecamatan Banjarmasin Utara, Kota Banjarmasin, Kalimantan Selatan 70121

Subjek penelitian yang dimuat dalam artikel ini adalah satu orang kepala sekolah SDIT Al-Firdaus, 1 orang guru laki-laki dan peremepuanPAI SDIT AL-Firdaus objek penelitian yang akan digali adalah keterampilan guru dalam mengajar materi fiqih yang dianggap tabu khususnya pada materithaharah pada materi kelas 4-6 di SDIT AlFirdaus. 
Jenis dan sumber data, yaitu data pokoknya berupa data yang diambil dari wawancara dengan dua orang guru PAI di SDIT Al-Firdaus dan data sekunder dalam penelitian ini berupa, data yang diambil dari wawancara dengan kepala sekolah.

Analisis yang digunakan dalam metode penelitian ini adalah deskriptif kualitatif dari wawancara yang dilakukan kepada informan selanjutnya pengorganisasian data, lalu memilah data yang relevan dengan penelitian dan setelah menemukan data yang relevan maka akan disintesiskan menggunakan teori yang berkaitan atau relevan dengan data yang diperolah dilapangan (Aspers \& Corte, 2019)

\section{HASIL DAN PEMBAHASAN \\ Hasil}

Materi fiqih yang dianggap tabu untuk disampaikan oleh pendidik kepada peserta didik, akan terasa tabu jika disampaikan saat di dalam kelas dikarenakan efek dari peserta didik yang merasa malu untuk mengungkapkan mereka sudah baligh atau haid, berangkat dari hal tersebut maka terjadilah rasa tabu atau canggung dalam menyampaikan materi tersebut. Materi fiqih akan dinaggap tabu jika disampaikan di dalam kelas dengan peserta didik yang heterogen atau bercampur antara perempuan dan laki-laki, penyampaian materi fiqih yang tabu tetap harus disampaikanmeskipun tidak terlalu mendetail hanya yang bersifat umum dan sesuai dengan kapasitas peserta didik.

Keterampilan yang dimiliki guru dalam penyampaian materi fiqih tersebut dimulai dengan keterampilan mengkondisikan kelas, kelas yang awalnya tidak kondusif karena ada anak yang merasa malu tentang materi fiqih tabu, sehingga membuat adanya sedikit keributan di dalam kelas, hal ini dapat diatasi dengan mengkondisikan kelas. Selain dengan cara mengkondisikan suasana kelas untuk bisa dengan kondusif menyampaikan matreri, ada hal lain yang dapat membantu guru guna bisa menyampikan materi fiqih tabu dengan baik. Yaitu melalui media video pembelajaran keterampilan guru dalam menggunakan media pembelajaran sangat juga penting.

Keterampilan guru selanjutnya dalam menyampaikan materi fiqih tabu bisa digunakan sebuah apersepsi, guru akan memulai pembelajaran dikelas dengan sebuah pertanyaann pancingan atau menghubungkan kembali pelajaran yang sudah dilakukan bisa juga apersepsi berguna sebagai penjajakan awal dalam setiap materi yang disampaikan. Menurut ustadz Jumani Apersepsi sangatlah membantu beliau untuk memberikan gambaran atau penjajakan awal untuk menyampaikan materi.

Penggunaan strategi dalam memberikan penjelasan sebuah materi kepada peserta didik sangatlah penting, karena kita bisa memberikan sebuah cara penyampaian yang berbeda dan menyesuaikan penyampaian kita terhadap keadaan lingkungan peserta didik. Strategi yang dipakai guru dalam menyampaikan materi yang tabu di SDIT AlFirdaus berupa memberikan Sent Setting atau melakukan pancingan awal untuk mengidentifikasi keadaan peserta didik untuk menentukan strategi apa yang harus atau cocok digunakan, juga untuk mengetahui bagaimana cara penerapan strategi yang dipilih agar tidak terlihat monoton saat diterapkan di dalam kelas. Selanjutnya pancingan awal tadi dibantu dengan penggunaan media pembelajaran berupa gambargambar berisi konsep seperti Puzzle yang memiliki makna terkait materi ajar, anak-anak akan sangat antusias saat melihat gambar-gambar tersebut dan berusaha menghubungkanya satu sama lain guna bisa memberikan tanggapan tentang materi ajar yang akan disampaikan oleh guru.

Kelas akan tidak terkondisikan jika kejenuhan sudah mulai memasukan pikiran peserta didik saat mengajar, keterampilan untuk mengembalikan kondisi kelas juga 
sangat dibutuhkan agar bisa maksimal memberikan pembelajaran. Dalam hal mengkondisikan kembali keadaan kelas diperlukan adanya media pembelajaran guna sebagai bahan selingan peserta didik bisa lebih menghilangkan jenuh. Selingan bisa berupapenggunaan media yang berbentuk gambar maupun video agar bisa memfokuskan kembali sekaligus menghilangkan jenuh peserta didik.Saat pembelajaran celetukan seorang anak akan bisa muncul karena materi fiqih yang tabu tersebu. celetukan anak tersebut direspons oleh teman sekelasnya maka akan menimbulkan keributan ditengah pembelajaran media pembelajaran akansangat membantu guna mengkondisikan kembali keadaan suasana kelas. Media pembelajaran akan membantu kita dalam memberi penjelasan secara operasional konkret sangatlah perlu dilakukan dalam pembelajaran materi fiqih yang dianggap tabu pada jenjang sekolah dasar. Media pembelajaran akan bisa digunakan secara tepat apabila seorang guru memiliki keterampilan dalam memilih juga sesuai dengan tujuan digunakannya media pembelajaran tersebut. Perlu penyampaian konkret tidak abstrak berkenaan dengan pemahaman atau perkembangan psikologi anak sekolah dasar sampai kepada operasional konkret, perlu kiranya penyampaian materi di sekolah dasar bersfiat langsung atau dengan bahasa yang jelas tidak terlalu abstrak, karena perkembangan pemikiran peserta didik pada jenjang sekolah masih berkutat di daerah operasional konkret untuk bisa menyampaikan secara konkret diperlukan media pembelajaran sebagai penunjang pembelajaran.

\section{Materi Fiqih Yang Tabu}

\section{Pembahasan}

Pembelajaran fiqih sangatlah urgen untuk bisa disampaikan dengan konkret dan sesuai dengan kapasitasnya, cakupan materi fiqih memang mamasuki ranah-ranah yang dianggap sebagian tabu untuk disampaikan kepada anak-anak, hal ini disebabkan materi tersebut mangandung unsur kedewasaan. Terlepas dari semua hal tersebut materi tersebut tetap harus disampaikan sebagai bekal pengatahuan awal kepada peserta didik, pengenalan di awal ini memang perlu karena peserta didik sebagai orang yang rasa ingin tahunya tinggi akan bisa memberikan akses sendiri kepada pembahasan yang terkait dengan materi tersebut. Jika hal ini sampai terjadi maka anak-anak akan mengonsumsi informasi tanpa ada bimbingan dan filter langsung dari seorang yang sudah terdidik atau dewasa (Wahyudin, 2020). Apalagi perkembangan zaman atau era digitalisasi yang sedang kita rasakan ini membuat semuanya bisa dilakukan dengan berbekal sebuah perangkat ponsel pintar kita sudah bisa melakukan semuanya dengan mudah mulai dari memasan makanan sampai kepada tempat akomodasi, semudah itu dalam melakukan akses ke internet (Rohadi, 2018). Kemudahan ini bisa digunakan peserta didik untuk mengakses informasi tanpa ada filter sama sekali, gunanya seorang pendidik dalam hal ini bisa memberikan terlebih dahulu materi yang tabu dalam fiqih, yaitu materi yang menyangkut, Mandi Wajib, Haid pembatal puasa seperti jimak, keluar mani dan lain sebagainya. Materi ini memang tabu disampaikan secara detail terhadap peserta didik jenjang sekolah dasar, tetapi bukan tidak perlu disampaikan tetapi malah sebaliknya, harus disampaikan dengan keterampilan atau cara yang relevan dengan keadaan peserta didik jenjng sekolah dasat ini.

\section{Keterampilan Guru Mengkondisi Kelas}

Efektivitas pembelajaran akan bisa maksimal bila kondisi kelas bisa normal atau tidak dalam ribut maupun jenuh. Penyampaian materi bahan ajar akan sangat berpengaruh dengan kondisi kelas, tidak memungkinkan apabila guru tetap melanjutkan 
pembelajaran sedangkan keadaan kelas sedang ribut. Maka dari itu perlu seoarng guru memiliki keterampilan untuk mengkondisikan kelas. Keterampilan mengkondisikan kelas ini merupakan Kemampuan dasar mengajar yang dapay membantu terwujudnya tujuan pembelajaran, selain dapat membantu dalam mencapai kondisi belajar yang menyenangkan, khususnya bagi guru tentang bagaiman menciptakan suasanya belajar yang menyenangkan juga membantu guru untuk bisa menguasai kelas dengan sepenuhnya (Ramli, 2017).

Munculnya keterampilan mengajar berupa mengkondisikan kelas tidak serta langsung muncul dan dikuasai oleh seorang guru, melainkan keterampilan mengajar ini dibentuk dari pelatihan dan pendidikan serta implementasi prinsip belajar yang dikelola oleh guru dengan menggunakan keterampilan yang didapatkan melalui pendidikan maupun pelatihan(Safitri \& Uep, 2016). Keterampilan seoramg guru untuk bisa mengkondisikan tidak hanya langsung bisa terasah setelah mendapatkan ilmunya melalui pelatihan maupun pembimbingan, tetapi keterampilan dalam mengkondisikan kelas ini akan selalu teraah seiring berjalannya waktu. Kemampuan seorang guru dalam mengkondisikan kelas juga harus berkembang sesuai dengan perkembangan zaman dalam era digital ini dimana anak-anak sudah bisa menggunakan perangkat digital dengan mahir akan memberikan pengaruh terhadap sikap dan perilakunya (Wahyuni, 2020).

Keterampilan mengkondisikan kelas sangat perlu untuk dikembangkan setiap waktu, karena proses belajar tidak hanya dilihat seberapa banyak materi yang disampaikan tetap, hasil akhir untuk memenuhi tujuan pembelajaran (Rozana, Jufrida, \& Basuki, 2018). Sebagai pengelola kelas guru bertanggung jawab memelihara lingkungan dan suasana kondusif serta memberikan bimbingan secara intelektual dan sosial mengkondisikan keadaan dikelas atau bisa kita kenal dalam bahasa manajemen pengelolaan kelas. Pengelolaan kela tidak mudah seorang guru bisa membaca kondisi kelas, dalam hal ini seorang guru harus bisa melihat masing-masing karekter peserta didik. Jika seorang guru tidak dapat melihat hal seperti itu maka akan susah untuk bisa mengkondisikan kelas dengan baik. Pemahaman tentang karakter peserta didik diperlukan guna dapat menciptakan suasana belajar yang kondusif, juga perlu dikuatkan lagi guru juga harus bisa mengkondisikan kelas dengan melakukan pemcahan maalah yang terjadi.

Adanya keterampilan mengkondisikan kelas merupakan usaha yang nyata guna mencapai tujuan pembelajaran, dengan iklim pembelajaran yang sudah di atur dan dapat dikendalikan jika terjadi gangguan dalam pembelajaran. Penyedian fasilitas belajar yang kondusif adalah tugas utama guru, dengan terkondisinya suasana belajar. Dapat disimpulkan bahwa keterampilan guru mengkondisikan kelas dapat memberikan pemahaman juga hasil belajar yang sesuia dengan tujuan pembelajaran. Jika tujuan pembelajaran dapat tercapai dengan tepat maka bukan tidak mungkin prestasi belajar peserta didik ikut menuingkat (Arumsari, 2017).

\section{Keterampilan Guru Dalam Melakukan Apersepsi}

Guru profesional haruslah menguasai 8 keterampilan dasar mengajar antara lain keterampilan bertanya,keterampilan memberikan penguatan, keterampilan mengadakan variasi, keterampilanmenjelaskan, keterampilan membuka dan menutup pelajaran, keterampilan membimbingdiskusi kelompok kecil, keterampilan mengelola kelas, keterampilan mengajar kelompok kecildan perseorangan. Kemampuan membuka dan menutup pelajaran atau dapat katakan apersepsi, Apersepsi berasal dari kata Apperception yang artinya menafsirkan buah pikir dan menyatukannya dengan 
pengalaman yang telah dimiliki. Pengertian lain menyebutkan bahwa apersepsi adalah kesadaran seorang untuk berasosiai dengan apa yang dimiliki diikuti dengan pengolahan sehingga kesan yang dulu terjadi menjadi lebih luas memberikan apersepsi pada awal pembelajaran meingkatkan kesiapan siswa dalam kegiatan belajar. Memberikan penguatan merupakan bentuk respon baik verbal maupun non verbal guna memberikan informasi atau umpan balik (feed back) kepada siswa untuk memberi dorongan ataupun koreksidalam penggunaannya guru akan memberikan pancingan diawal agar peserta didik bisa mencari benang merah untuk pelajaran yang disampaikan oleh guru, selain itu fungsi apersepsi juga sebagai stimulus untuk peserta didik dari guru, agar dapat mengikuti pembelajaran dengan baik. Pada awal pembelajaran biasanya guru langsung melakukan absensi setelah kegiatan pembuka pembelajaran. hal ini membuat kondisi kelas kurang kondusif untuk melakukan pembelajaran karena konsentrasi siswa masih belum terbangun oleh karena itu siswa merasa kesulitan dalam mencerna materi. Berdasarkan studi Hilman Ramdiana masih banyak guru yang tidak mengawali pembelajaran dengan melakukan apersepsi yang merupakan inti dari kegiatan pendahuluan Thorndike menyebutkan bahwa keberhasilan proses belajar dipengaruh oleh kesiapan belajar siswa. Secara neorologi kesiapan belajar ini dipengaruhi kondisi gelombang otak yang terbagi atas gelombang Alfa, Bet dan Teta. Gelombang otak Alfa ini adalah kondisi yang paling cemerlang dalam memulai pembelajaran karena neuron berada dalam kondisi harmoni (seimbang)(Nugroho \& Ratri, 2020).

Apersepsi dapat membuat materi baru mudah diterima, memberikan warna pada materi baru melalui materi atau pengalaman terdahulu sehingga menjadi satu kesatuan yang integral, menumbuh kembangkan ketertarikan (interest) dan perhatian (attention) peserta didik dalam belajar, memunculkan keterbukaan pada peserta didik untuk menerima pengalaman atau materi baru, dan menumbuhkan kembangkan motivasi belajar. Sebelum memilih apersepsi perlu adanya pemilihan strategi belajar yang sesuai dengan materi yang ingin disampaikan. Strategi antara lain adalah langkah yang harus dilakukan lembaga pendidikan untuk memastikan tercapainya tujuan pembelajaran strategi juga variasi pola umum untuk mengajar bahkan dimasa pandemi sekarang strategi pembelajaran sudah berkembang mulai menggunakan website, media sosial, teleconference hingga e-learning hal ini menandakan bahwa strategi pembelajaran sudah berkembangan bahkan kedalam dunia daring. , koneksi ini harus dibangun agar mereka merasanya nyaman dan pembelajaran menjadi lebih efektif. Langkah solutif untuk tercapainya tujuan pembelajaran dengan memperbaiki pola pembelajaran

Pentingnya apersepsi dalam pembelajaran tidak dapat dianggap kecil khususnya dalam menyampaikan materi fiqih yang tabu, jika diawal pembelajaran sudah tidak bisa memberikan pancingan atau stimulus untuk menyampaikan materi dengan maka akan membuat langkah selanjutnya kurang maksimal. Hal bisa dikatakan demikian karena kemampuan apersepsi berguna untuk merangsa peserta didik(Prasetyo \& et al, 2020).

\section{Keterampilan Guru Dalam Menggunakan Strategi}

Pembelajaran yang sekarang sudah berjalan di sekolah memiliki problema serius, berupa cepat jenuhnya peserta didik dalam belajar. Akibat dari kejenuhan mengakibatkan sulitnya tercapai tujuan pembelajaran, guru kebanyakan hanya memberikan banyak teori kepada peserta didik. Teori yang disampaikan hanya sebatas disampaikan tanpa memadang apakah peserta didik dapat mencerna, memahami atau menyerap pembelajaran secara menyeleruh. Permasalahan seperti ini akan membawa sebuah ketertinggalan. 
Banyak faktor yang mempengaruhi pembelajaran menjadi jenuh dalam pandangan peserta didik salah satunya adalah penggunaan strategi pembelajaran yang menoton. Bisa jadi seorang guru bisa menggunakan banyak strategi, tetapi implementasi atau pembawaan guru saat di kelas tidak bisa beradaptasi. Atau gaya penerapan strategi yang dilakukan oleh guru terkesan monoton (Asmani, 2014a).

Strategi dalam belajar mengajar merupakan sebuah pola umum dalam kerangka pembelajaran. Dalam pembelajaran selain pemelihan strategi yang tepat juga keterampilan dalam menggunakannya sangatlah perlu untuk diasah. Meskipun guru menguasai strategi pembelajaran, tetapi cara penerapannya dikelas tidak tepat maka bisa jadi yang awalnya mau membuat kelas aktif, berubah menjadi sebuah pembelajaran yang monoton (Usman, 2010).

Disamping itu strategi yang baik akan membangun interaksi antara guru dan murid, koneksi ini harus dibangun agar mereka merasanya nyaman dan pembelajaran menjadi lebih efektif. Langkah solutif untuk tercapainya tujuan pembelajaran dengan memperbaiki pola pembelajaran dengan menggunakan strategi yang kiranya efektif. Strategi pembelajaran bisa kita anggap penghubung antara guru dengan peserta didik. Selama ini, peradigma di sekolah dalam proses belajar mengajar di kelas masih banyak yang belum sesuai dengan keadaan peserta didik. Guru menganggap peserta didik hanya sebatas penonton yang melihat mereka memamerkan berbagai keahlian ataupun penyampaian materi yang dikuasai oleh guru. Peserta didik dibuat terpesona dengan penampilan guru, terpaku dengan petuah-petuahnya. Hasilnya aktivitas peserta didik dalam pembelajar kurang akibatnya mereka hanya sebagai pendengar dalam belajar dan peminta dalam belajar. Peserta didik tidak bisa aktif untuk melakukan eksplorasi materi pembelajaran maupun menumbuhkan nalar kritis dalam pembelajaran.

Pembelajaran dengan konsep murid yang pasif hendaknya bisa dihilangkan atau diubah menjadi murid yang aktif. Murid yang pasif tidak akan bisa mengubah atau membentuk generasi menjadi sebuah generasi yang mandiri, kritis dan kreatif. Cara mengubah hal tersebut dengan cara memberikan keatifan kepada peserta didik.Kita sepakat bahwa proses pembelajaran yang dilaksanakan di dalam kelas peserta didik tidak hanya dijadikan penonton tetapi peserta didik diikutkan aktif saat proses pembelajaran. Secara hakita belajar berarti memberikan pembelajaran kepada peserta didik untuk bisa mengembangkan potensi mereka melalui bertanya, menalar, ekplorasi dan dapat memacahkan permasalahn-permasalahan dalam kehidupan sehari-hari. Untuk bisa mencapai agar peserta didik aktif yaitu melalui penggunaan strategi pembelajaran yang tidak monoton dalam penerapannya(Rasyid, 2017).

Penerapan strategi dalam pembelajaran bisa kita artikan sebagai garis besar haluan dalam bertindak di dalam proses belajar mengajar, atau pola-pola umum kegiatan pembelajaran antara peserta didik dengan gurunya. Ada empat keterampilan dasar guru yang harus dipenuhi guna bisa menerapkan strategi pembelajaran dengan tepat atau tidak monoton, karena jika seorang guru menerapkan strategi pembelajaran tetapi cara penetapannya bersifat mononton, bukan hasil belajar atau tujuan pembelajaran yang terpenuhi tetapi akan muncul sebuah kejenuhan bagi peserta didik dalam belajar. Dari tersebutlah maka perlu seorang guru dapat menguasai keterampilan dalam menerapkan strategi pembelajaran, adapun keterampilan tersebut adalah sebagai berikut:

1. Mengidentifikai tingkah laku dan kepribadian peserta didik sebagaimana yang diharapkan.

2. Memilih sistem pendekatan belajar berdasarkan situasi kelas 
3. Memilih dan menetapkan proedur, metode dan teknik belajar yang efektif sehingga dapat menjadi pegangan saat pembelajaran.

4. menetapkan norma-norma dan batas minimum keberhasilan, sehingga dapat dijadikan bahan evaluasi saat melakukan evaluasi pembelajaran(Asmani, 2014b)

Berdasarkan teori yang ada dipaparkan keterampilan seorang guru dalam penerapan strategi pembelajaran harus mencakup empat di atas, dalam temua yang didapat saat wawancara dengan informan di SDIT Al-Firdaus mereka menggunakan Sent Settting dalam istilah mereka dinamakan seperti itu, maksud dari Sent Settingtersebut adalah mereka melakukan identifikasi awal tingkah laku atau keadaan peserta didik saat di dalam kelas, gunanya untuk mengetahui bagaimana cara penerapan strategi yang tepat dan relevan terhadap keadaan peserta didik pada waktu tersebut.

Selain bertujuan untuk identifikasi Sent Settingjuga dilakukan untuk menentukan pendekatan yang tepat untuk memulai pembelajaran juga penerapan strategi dalam pembelajaran. Fungsi Sent Settingjuga mencakup penjajakan awal penggunaan teknik, prosedur dan metode pembelajaran yang bersinergi dengan strategi pembelajaran, dan sebagai bahan untuk memberikan evaluasi pengajaran yang dilakukan guru.

\section{Keterampilan Guru Dalam Menggunakan Media Pembelajaran}

Penggunaan media pembelajaran terbukti meningkatkan motivasi serta hasil belajar, Peranan media pembelajaran merupakan kesatuan di didunia pendidikan. Media pembelajaran membantu menyampaikan pesan dan minat belajar kepada peserta didik media diambil dari bahasa latin Medius yang artinya perantara(Mustaqim, 2017). Media merupakan alat bantu dalam proses belajar mengajar media sebagai salah satu penunjang pembelajaran menentukan berhasil tidaknya suatu pembelajaran media pendidikan juga meminimalkan kesalahan komunikasi saat proses belajar berlangsung dengan mengubah pesan komunikasi menjadi simbol verbal maupun nonverbal hal ini disebut dengan encoding. Oleh sebab itu guru harus mengetahui dan menguasai penggunaan media pembelajaran, disamping itu diperlukan keterampilan dalam memilih media tersebut pemanfaatan media dikaitkan dengan kenaikan kualitas pembelajaran yang diharapakan tentang bagaimana membuat suasana belajar lebih bermakna(Atsani, 2020).

Media pembelajaran adalah alat bantu mengajar yang turut membantu mempengaruhi iklim kondisi dan lingkungan belajar ciptaan guru di dalam kelas. Selain itu media pembelajaran juga mampu merangsang semua indera, karena dalam pembelajaran jika alat indera terangsang akan siap untuk menerima semua materi pembelajaran untuk diolah dan dipahami oleh peserta didik, pengolahan informasi tersebut akan bertahan menjadi sebuah ingatan. Hal seperti itulah yang diharapkan dalam pembelajaran peserta didik mampu mengolah informasi yang diberikan oleh guru.

Melihat betapa pentingnya penggunaan media pembelajaran maka sebelum guru menggunakannya dalam pembelajaran terlebih dahulu harus membekali diri dengan pengetahuan menggunakan media tersebut. Karena banyak guru yang tidak mengerti tentang media pembelajaran dan cara memilih juga menggunakannya. Selain itu guru tidak hanya cukup mengetahui tentang media terebut juga harus mengetahui bagaimana cara menggunakannya. Menggunakan media pembelajaran harus perlu keterampilan yang mempuni agar saat memakai media dalam pembelajaran sesuai hasilnya dengan harapan (Alwi, 2017).

Salah satu unsur yang penting dalam proses pembelajaran adalah media yang mendukungnya. Selain unsur penting media pembelajaran juga berguna memperkaya 
wawasan peserta didik. Pemakaian media pembelajaran dapat menumbuhkan minat belajar peserta terhadap hal baru. Pembelajaran akan terasa menyenangkan jika ada unsur media yang membantu, media pembelajaran secara formal sudah diakui dapat membantu untuk mencapai tujuan pembelajaran, sehingga semakin banyak perkembangan media pembelajaran untuk menjawab berbagai problem dalam pembelajaran. Sebelum menentukan media yang digunakan guru harus memiliki keterampilan untuk memilih media pembelajaran, keterampilan tersebut ada terbagi lima yaitu sebagai berikut:

1. Penggunaan media perlu disesuiakan kebutuhan dan karakteristik peserta didik.

2. Penggunaan media harus sesuai dengan tujuan pembelajaran yang sudah dirumuskan.

3. Penggunaan media harus sesuai dengan materi yang ingin di sampaikan.

4. Penggunaan Media harus Sesuai dengan taraf berpikir peserta didik

5. Penggunaan media harus Efisien dalam menggunakannya(Nurrita, 2018).

Pentingnya media dalam sebuah pembelajaran melatar belakangi kenapa seorang guru harus memiliki keterampilan untuk menggunakannya, berdasarkan data yang didapatkan peneliti di SDIT Al-Firdaus para guru menggunakan media pembelajaran harus bisa menyesuaikan dengan kebutuha dan karakteristik peserta didik, seperti menggunakan gambar tentang praktik mandi wajib untuk mempermudah peserta didik yang masih pemahaman secara operasional konkret.

Media yang digunakan di SDIT Al-Firdaus akan menyesuaikan dengan tujuan pembelajaran dari awal, seperti penggunaan media berupa video pembelajaran untuk memberikan penjelas tentang sebab-sebab seorang anak laki-laki mimpi basah atau baligh. Materi tersebut jika hanya dijelaskan secara lisan maka masih banyak pertanyaan, jika dibantu oleh media maka akan lebih banyak informasi yang tersampai untuk memberikan pemahaman kepada peserta didik. Selajan dengan itu media pembelajaran yang digunakan akan bersinergi antara materi sebagai contoh lagi dalam memberikan penjelasan tentang haid maka guru akan menggunakan media gambar untuk memberikan pemahaman kepada peserta didik.

Taraf berpikir jenjang sekolah dasar masih pada taraf operasional konkret, maka dari itu diperlukan media untuk lebih mudah dalam menjelakannya, seperti contoh memberikan gambar darah merah untuk memberikan gambaran tentang materi haid.

Efesiensi waktu juga diharapakan dalam menggunakan media, jika waktu yang tersedia hanya sebantar maka media yang digunakan harus dapat mengikuti waktunya. Dalam penggunaan media pembelajaran di SDIT Al-Firdaus bisa menyesuiakan lamanya belajar dengan media yang digunakan, seperti contoh penggunaan video sebagai media pembelajaran hanya menggunakan video singkat dan selanjutnya diteruskan oleh guru dalam menjelaskan materi kepada peserta didik.

\section{PENUTUP}

Materi fiqih memang ada yang bersifat tabu untuk disampaikan kepada anak-anak, hal ini sebabkan belum masuknya kapasitas anak-anak dari segi umur maupun psikologis dalam mengetahui hal tersebut, meskipun hal tersebut tabu tetap harus disampaikan untuk menghindari agar tetap dalam pengawasan orang dewasa atau seorang guru. Untuk bisa menyampaikan materi tersebut dengan tepat dan sesuia dengan kapasitas peserta didik di tingkat dasar, maka guru harus menguasai berbagai macam keterampilan. Adapun keterampilan yang ditemukan oleh peneliti adalah sebagai berikut: Pertama keterampilan mengkondisikan kelas, keterampilan diperlukan karena 
untuk menyampaikan yang mudah saja perlu kondisi kelas yang kondusif apalagi menyampaikan materi yang bersifat tabu, Kedua keterampilan melalukan apersepsi atau pancingan awal bisa juga disebut stimulus untuk peserta didik agar sudah mulai menalar materi yang disampaikan, Ketiga keterampilan menggunakan strategi pembelajaran, keterampilan berguna karena tidak semua guru bisa menerapkan strategi pembelajaran dengan bagus. Guru bisa mengetahui banyak strategi tetapi dalam penerapam tidak bisa menyesuaikan dengan keadaan kelas, maka strategi akan menjadi terasa monoton, Keempat keterampilan menggunakan media pembelajaran, dalam materi fiqih yang tabu tidak cukup hanya dijelaskan secara verbal, tetapi memerlukan sebuah media seperti gambar atau video. Dari hasil temuan yang didapatkan akan memunculkan simpulan berapa keterampilan guru dalam hal mengkondisikan kelas, melakukan apersepsi, menggunakan strategi dan menggunakan media sangat penting guna memberikan pemahaman kepada peserta didik dalam pembelajaran fiqih yang tabu.

\section{DAFTAR PUSTAKA}

Alfinnas, S. (2018). Arah Baru Pendidikan Islam di Era Digital. FIKROTUNA, 7(1), 803-817. https://doi.org/10.32806/jf.v7i1.3186

Alwi, S. (2017). Problematika Guru Dalam Mengembangkan Media Pembelajaran. Itqan, $8(2)$.

Alwiyah, D., \& Imaniyati, N. (2018). KETERAMPILAN MENGAJAR GURU DAN KESIAPAN BELAJAR SISWA SEBAGAI DETERMINAN TERHADAP HASIL BELAJAR SISWA. Jurnal MANAJERIAL, 17(1), 95. https://doi.org/10.17509/manajerial.v17i1.9767

Amelia, F. R. (2020). Pengaruh Media Sosial Terhadap Peningkatan Kesehatan Reproduksi Perempuan. Al-Wardah: Jurnal Kajian Perempuan, Gender dan Agama, 14(2).

Arumsari, D. (2017). Pengaruh Media Pembelajaran Dan Keterampilan Pengelolaan Kelas Terhadap Prestasi Belajar Siswa SMK Negeri 5 Madiun. Assets: Jurnal Akuntansi dan Pendidikan, 6(1), 13. https://doi.org/10.25273/jap.v6i1.1290

Asmahasanah, S., Sa'diyah, M., \& Ibdalsyah, I. (2018). Analisis Keterampilan Mengajar Guru dan Penanaman Nilai Positif Melalui Pemanfaatan Kebun Sekolah. Sekolah Dasar: Kajian Teori dan Praktik Pendidikan, 27(2), 167-173. https://doi.org/10.17977/um009v27i22018p167

Asmani, J. M. (2014a). Tips Membangun Komunitas Belajar Di Sekolah. Yogyakarta: Diva Press.

Asmani, J. M. (2014b). Tujuh Tips Aplikasi PAIKEM. Yogyakarta: Diva Press.

Aspers, P., \& Corte, U. (2019). What is Qualitative in Qualitative Research. Qualitative Sociology, 42(2), 139-160. https://doi.org/10.1007/s11133-019-9413-7

Atsani, G. M. Z. (2020). TRANSFORMASI MEDIA PEMBELAJARAN PADA MASA PANDEMI COVID-19. Al-Hikmah Jurnal Studi Islam, 1(1).

Hadi, F. R. (2021). KESULITAN BELAJAR SISWA SEKOLAH DASAR DALAM MENYELESAIKAN SOAL HOTS MATEMATIKA BERDASARKAN TEORI NEWMAN. MUALLIMUNA : JURNAL MADRASAH IBTIDAIYAH, 6(2), 14.

Ichsan, I. Z., Rahmayanti, H., Purwanto, A., Sigit, D. V., Kurniawan, E., Dewi, A. K., ... Marhento, G. (2020). COVID-19 DAN E-LEARNING: PERUBAHAN STRATEGI PEMBELAJARAN SAINS DAN LINGKUNGAN DI SMP. JINoP (Jurnal Inovasi Pembelajaran), $\quad 6(1), \quad 50$. https://doi.org/10.22219/jinop.v6i1.11791 
Juandi, A., \& Sontani, U. T. (2017). Keterampilan dan kreativitas mengajar guru sebagai determinan terhadap prestasi belajar siswa. 2(2).

Maryance. (2017). Pelaksanaan Keterampilan Dasar mengajar Guru Dalam Pembejalaran Pendidikan Agama Islam Di SMP Negeri 17 Palembang. Jurnal Realita, 2(2).

Maulidiyah, E. C. (2018). PENANAMAN NILAI-NILAI AGAMA DALAM PENDIDIKAN ANAK DI ERA DIGITAL. Martabat: Jurnal Perempuan dan Anak, 2(1), 71-90. https://doi.org/10.21274/martabat.2018.2.1.71-90

Mustaqim, I. (2017). PENGEMBANGAN MEDIA PEMBELAJARAN BERBASIS AUGMENTED REALITY. Jurnal Edukasi Elektro, 1(1).

Nugroho, R. M., \& Ratri, H. (2020). APERSEPSI PEMBELAJARAN MELALUI STAND-UP COMEDY UNTUK MENINGKATKAN MOTIVASI BELAJAR MAHASISWA DENGAN METODE CERAMAH DI STKIP PGRI PONOROGO. Jurnal Pendidikan, 21(2).

Nurcahyo, J. (t.t.). PENGARUH APERSEPSI VISUAL DAN MINAT BELAJAR SISWA TERHADAP PRESTASI BELAJAR SISWA PADA MATA PELAJARAN TEORI PROSES PEMBUBUTAN DASAR DI SMK N 2 PENGASIH KULON PROGO. 5.

Nurrita, T. (2018). PENGEMBANGAN MEDIA PEMBELAJARAN UNTUK MENINGKATKAN HASIL BELAJAR SISWA. MISYKAT: Jurnal Ilmu-ilmu AlQuran, Hadist, Syari'ah dan Tarbiyah, 3(1), 171. https://doi.org/10.33511/misykat.v3n1.171

Prasetyo, A., \& et al. (2020). Comedy Sebagai Apersepsi Dalam Pembelajaran. JKTP: Jurnal Kajian Teknologi Pendidikan, 3(2).

Ramli, A. (2017). PEMBELAJARAN DALAM PERSPEKTIF KREATIVITAS GURU DALAM PEMANFAATAN MEDIA PEMBELAJARAN. Lantanida Journal, 4(1).

Rasyid, M. A. (2017). Hadits-Hadits Tarbawi. Yogyakarta: Diva Press.

Rohadi, L. (2018). Pengaruh Era Revolusi Industri 4.0 Terhadap Kompetensi Sumber Daya Manusia. Jurnal Manajemen Bisnis Indonesia, 6(1).

Rozana, T., Jufrida, J., \& Basuki, F. R. (2018). PENERAPAN MODEL PEMBELAJARAN POE UNTUK MENINGKATKAN KETERAMPILAN PROSES SAINS KELAS XI SMAN 11 JAMBI. EduFisika, 3(02), 66-80. https://doi.org/10.22437/edufisika.v3i02.4541

Ruwaida, H. (2019). STRATEGI PEMBELAJARAN FIQIH THAHARAH DI SDN MUNDAR KECAMATAN LAMPIHONG KABUPATEN BALANGAN. $A l$ Madrasah: Jurnal Pendidikan Madrasah Ibtidaiyah, 167. https://doi.org/10.35931/am.v0i0.137

Safitri, E., \& Uep, T. S. (2016). KETERAMPILAN MENGAJAR GURU DAN MOTIVASI BELAJAR SISWA SEBAGAI DETERMINAN TERHADAP HASIL BELAJAR. Jurnal Pendidikan Manajemen Perkantor, 1(1).

Siagian, A. O., Martiwi, R., \& Indra, N. (2020). Kemajuan Pemasaran Produk Dalam Memanfaatkan Media Sosial Di Era Digital. Jurnal Pemasaran Kompetitif, 3(3), 44. https://doi.org/10.32493/jpkpk.v3i3.4497

Sulistiono, M. (2019). Implementasi Hybrid Learning Menggunakan Aplikasi Edmodo Pada Matakuliah Metode Penelitian Kualitatif. Elementeris: Jurnal Ilmiah Pendidikan Dasar Islam, 1(1), 57. https://doi.org/10.33474/elementeris.v1i1.2794

Syaifullah, A. (2020). Moderasi Islam dalam Kitab Sabilal Muhtadin: Kearifan Lokal Tanah Banjar. 2(1), 36. 
Tang, M. (2018). Pengembangan Strategi Pembelajaran Pendidikan Agama Islam (PAI) dalam Merespon Era Digital. FIKROTUNA, 7(1), 717-740. https://doi.org/10.32806/jf.v7i1.3173

Usman, B. (2010). Metodologi Pembelajaran Agama Islam. Jakarta: Ciiputat Press.

Wahyudin. (2020). Pembidangan Ilmu Fiqih. Jurnal Pendidikan Kreatif, 1(2).

Wahyuni, A. (2020). Sosialisasi Pentingnya Mengasah kemampuan Berpikit Kritis Bagi Guru Matematika di Era VUCA. Commnutiy Education Engagement Journal, 2(1).

Wijaya, D., Wibowo, H., Supriadi, D., \& Sopyan. (2020). Pendidikan Karakter Dalam Perspektif Islam. Jurnal Akrab Juara, 5(4), 7. 